\title{
CYSTICERCOSIS OF THE CENTRAL NERVOUS SYSTEM AND CEREBROSPINAL FLUID
}

\author{
IMMUNODIAGNOSIS OF 1573 PATIENTS IN 63 YEARS (1929-1992)
}

\author{
A. SPINA-FRANÇA *, J.A. LIVRAMEN'TO **, L.R. MACHADO **
}

\begin{abstract}
SUMMARY - Attention given to prophylaxis of neurocysticercosis (NC) is far beyond minimal needs among severial regions of the in-deveiopment world, and for this reason incidence of the disease persists high among them. This investigation was carried out to show the extent of the problem by analysing the incidence of NC in a region of Brazil (S'ão Paulo). CSF immunodiagnosis of NC by detecting antibodies to Cysticereus cellulosae in a neurodiagnostics laboratory is evaluated for this purpose. Cases studied in a 63-year period (19291992) are reviewed. Total cases in this period is 139,000 , and for $1,573(1.13 \%)$ diagnosis is NC. Special characteristics were not detected for colour and sex prevalence. Age bracket previalence is from 21 to 40 years old (55.3\%) high rates occurring for women between 21 to 30 years old, and for men between 31 to 40 . Cases distribution in five consecutive decades (1942-1991) shows no decreasing tendency: average incidence is $1 \%$ for the 50 years, and it is over this average for the last three decades. Data conf:rm that incidence continues expressively high throughout the 50 years covered by this study.
\end{abstract}

KEY WORDS: cysticercosis, central nervous system, cerebrospinal fluid, immunodiagnosis, incidence.

Neurocisticercose e liquido cefalorraqueano: imunodiagnóstico de 1573 pacientes estudados em 63 anos (1929-1992).

RESUMO - A atencão dada à profilaxia da neurocisticercose (NC) encontra-se aquém do mínimo necessário em várias regiōes do terceiro mundo, motivo pelo qual nelas a incidência da doenca continua alta. Esta investigação foi feita para mostrar a importancia do problema pela análise da incidência da $\mathrm{NC}$ em uma região do Brasil (São Paulo). Para tanto foram considerados os dados de um laboratório de neurodiagnóstico em que o imunodiagnóstico de NC é baseado na detecção de anticorpos a Cysticercus cellulosae no líquido cefalorraqueano (LCR). Os casos estudados no período de 63 anos (1929-1992) são revistos. O número de casos nesse período foi 139.000, o diagnóstico sendo $\mathrm{NC}$ em 1.573 deles $(1,13 \%)$. Não foram encontradas caracteristicas especiais de prevalência para cor e idade. A prevalência quanto la faixa etária se encontra entre 21 e 40 anos de idade (55,3\%), sendo maior para mulheres entre 21 e 30 anos de idade e, para homens entre 31 e 40. A distribuição dos casos em 5 décadas consecutivas (1942-1991) não mostra tendência a decréscimo: a incidência média foi $1 \%$ para os 50 anos, encontrando-se acima da média a incidência nas 3 últimas décadas. Esses dados confirmam que a inciđência se mantém expressivamente alta nos 50 anos abrangidos pelo estudo.

PALAVRAS-CHAVE: cisticercose, sistema nervoso central, liquido cefalorraqueano, imunodiagnóstico, incidência.

Interruption of taenia/cysticercus cycle is the best way for reducing the incidence of cysticercosis of the central nervous system (neurocysticercosis), as recognized since longtime 15 . Like the mentioned, other prophylactic measures for fighting neurocysticercosis (NC) have not been satisfactorily adopted in many regions of the in-development world with high incidence of NC. As a consequence, incidence rates reported for NC persist high among them 12, like in

CIN, Centro de Investigações em Neurologia, Faculdade de Medicina da Universidade de São Paulo (FMUSP) / LSF (Laboratório de Neurodiagnóstico): * Professor Emérito; ** Professor Assistente. Aceite: 15-julho-1992.

Dr. Antonio Spina-França - Caixa Postal 5199 - 01065-970 São Paulo SP - Brasil 
several regions of Brazil for instance 14. Periodically, neurologists noticize these high rates 17. Among good reasons for justifying these reports outstands the attempt to sensitize international health care organizations, like WHO and PAHO. However, there is a lack of information about the non declining tendency in the incidence of NC throughout the last decades, thus justifying a more effective politics of these organizations for fighting the disease.

The present investigation aims to contribute for the subject by analyzing data on the incidence of NC during the last five decades. Data are based on the immunodiagnosis of NC through detection of specific antibodies against Cysticercus cellulosae (anti-cyst) in the cerebrospinal fluid (CSF). They are provided by a reference neurodiagnostics laboratory (LSF) which is associated to the Neurology Investigation Center (CIN) of the Faculty of Medicine of the University of São Paulo (FMUSP). Since it was founded in 1929 and until the present time, the immunodiagnosis of NC in this laboratory is based on anti-cyst detection in the CSF by several immunologic methods, one summed to the other throughout the years: complement fixation test (CFT) at first, which gave place to CFT according to the Kolmer $1 / 5$ technique (CFTK) in 1953; indirect immunofluorescence test (IFT), in 1976; ELISA, in 1986; and passive hemagglutination test (PHT), in 1987. Critical evaluations of CSF immunodiagnosis of NC by these methods were periodically reported since 1940 up to present time 2-4,11,13. Anticyst were searched in this laboratory when indicated from 1929 till 1938, and systematically since 1939 up to the present time. The five consecutive decades for which the incidence of the CSF immunodiagnosis of NC is evaluated cover the years from 1942 to 1991 .

\section{MATERIAL AND METHOD}

Data from 139,000 patients seen from October-1929 to June-1992 were retrospectively analyzed. All patients were submitted to CSF exam for evidencing primary impairment of the nervous system or involvement of the nervous system secondary to systemic diseases. Cases included are all those who have anti-cyst detected in the CSF by CFT, CFTK, IFT, ELISA and PHT. Cases excluded were those with crossed results for anti-cyst detection tests (15 cases) or false-positive tests (13 cases).

In order to evaluate distributions were consecutively analyzed data from: 250 cases for colour and social-economic condition; 800 cases for sex and age. For them cases considered were taken from 1992 to the preceding years.

For evaluating distribution by decades, cases were consecutively taken year-by-year from 1942 to 1991 , covering 50 years (1502 cases: $95,5 \%$ of total cases number).

\section{RESULTS}

Immunodiagnosis of NC through CSF detection of anti-cyst was made in 1,573 cases from the total 139,000 patients $(1.13 \%)$. The first result (CFT) was reported on October-1929 and it was negative. The first positive result was reported on June-1934.

Colour distribution of cases is: $81.6 \%$ white, $16.4 \%$ negro or mulatto, and $2.0 \%$ yellow people. Sex distribution is: male $50.6 \%$ and female $49.4 \%$. Social-economic condition in report to the health care system is: dependent $54.8 \%$ and non-dependent people $45.2 \%$.

Age range is 1 to 82 years old. The large number of cases is diagnosed between 21. and 40 years old (55.3\%). Distribution of cases according to sex and age bracket is shown in Table 1. The large number for men is from 31 to 40 years old (29.9\%), and for women from 21. to $30(30.1 \%)$. Number is higher until 20 years old for women $(20.5 \%)$ than for men (16.8\%).

Mean incidence of NC throughout the 50 years covered by this strudy (1942-1991) is $0.996 \%$. An increasing tendency in the incidence is registered from one decade to the other during these 50 years (Table 2) as illustrated by seasonal smoothing of data (Fig. 1).

\section{COMMENTS}

Investigations on the immunodiagnosis of NC were first stimulated by Metchnikoff at the Pasteur Institute (Paris) in the beginning of this century. 
Table 1. Sex and age bracket distribution for 800 cases with CSF immurodiagnosis of cysticercosis of the CNS.

\begin{tabular}{|c|c|c|c|}
\hline \multirow[b]{2}{*}{ Age (years) } & \multicolumn{3}{|c|}{$\operatorname{Sex}(\%)$} \\
\hline & $\mathbf{M}$ & $\mathbf{F}$ & $\mathbf{M}+\mathbf{F}$ \\
\hline-5 & 3.45 & 4.05 & 3.75 \\
\hline $6-10$ & 4.20 & 4.81 & 4.50 \\
\hline $11-20$ & 9.14 & 11.65 & 10.38 \\
\hline $21-30$ & 25.93 & 30.13 & 28.00 \\
\hline $31-40$ & 29.88 & 24.56 & 27.25 \\
\hline $41-50$ & 13.58 & 11.90 & 12.75 \\
\hline $51-60$ & 8.64 & 7.59 & 8.12 \\
\hline $60-$ & 5.18 & 5.31 & 5.25 \\
\hline Total $(\%)$ & 100 & 100 & 100 \\
\hline
\end{tabular}

M, masculin; F, feminin

Table 2. CSF immunodiagnosis of cysticercosis of the CNS: incidence (\%) in five consecutive decades (1942-1991)

Decade Incidence

\begin{tabular}{cc}
\hline \hline $1942-1951$ & 0.22 \\
$1952-1961$ & 0.90 \\
$1962-1971$ & 1.10 \\
$1972-1981$ & 1.29 \\
$1982-1991$ & 1.47 \\
Mean & 0.996 \\
\hline
\end{tabular}

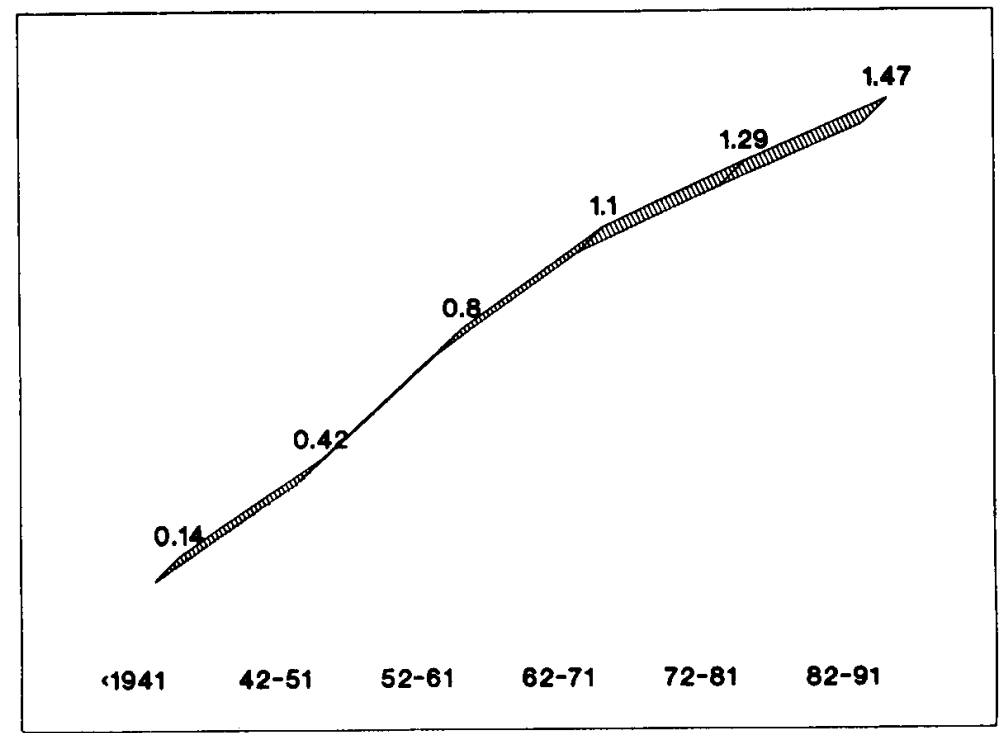

Fig. 1. CSF immunodiagnosis of cysticercosis of the CNS: seasonal smoothing of incidence (\%) through five consecutive decades (1942-1991). 
The proposed method was based on the complement fixation technique, and was scheduled in 1909 by Weinberg 16. First positive results in blood serum and in CSF were registered in Brazil in 1911 by Moses 6 . Researchers from several countries with high incidence of cysticercosis began to work on the subject since then. In Brazil first reports are those of Pessoa et al. 8 in 1927, and those of Monteiro Sales 5 in 1934. The latter particularly deals with the CSF immunodiagnosis of NC. Lange 2 described in 1940 the CSF syndrome of NC, and considered the anti-cyst detection as essential for characterizing this syndrome. Lange's studies on the subject began in 1928, and in the next year he introduced the anti-cyst detection in the CSF by CFT at the Neurologic Clinics of FMUSP and in its own laboratory, the LSF at present time. People who followed his steps optimized anti-cyst detection in the CSF through other proposed techniques or methods, and critically revisited their usefulness for diagnosing $\mathrm{NC}$ in several occasions, as quoted in the first part of this paper. The first trial was registered in 1929, and proved negative; the first positive result was registered in 1934 . Up to June-1992, 1,573 cases of NC were diagnosed through anti-cyst detection in the CSF for the 139,000 patients studied at LSF $(1.13 \%)$.

Reports on the subject from many other investigation centers are continuously registered, as in the city of São Paulo at the Escola Paulista de Medicina 9,10 for instance. In 1956 Nieto 7 reported that anti-cyst detection in the CSF is largely used in Mexico for diagnosing NC, and it continues to prove useful according to his school 1 . Nevertheless, it is a common experience nowadays that anti-cyst detection in the CSF does not cover all cases who have NC. Neuroimaging may amplify numbers which characterize the prevalence and the incidence of NC. However, data from this research are representative.

Prevalence of white people among patients with NC closely follows the racial distribution of Brazilian population. Sex distribution shows no difference for the male/female rate. Age distribution shows prevalence of cases from 21 to 40 years old. However, NC is registered in all age brackets: the younger patient was 1 year-old and the older 92. These data agree with those of Takayanagui and Jardim (1983) for 500 cases. Taken together distribution by age bracket and by sex for 800 cases of the present series a different pattern of distribution was detected. Prevalence for women was found high between 21 and 30 years old, and for men between 31 and 40 . Also, until 20 years old NC was detected more frequently in women than in man. This difference may result from social conditions. In fact, exposition of women to taenia/cysticercus cycle usually occurs earlier than for man. Girls' education firstly envisages domestic activities, as preparation of meals; boys are preferentially directed towards activities which can increase the family's income. These aspects are particularly registered among people living in poor socio-economic conditions. Manytimes, their health conditions solely depend of medico-social structures scarcely maintained by governments. High rates shown in this study for people dependent of health care systems are illustrative on this subject.

Incidence of $\mathrm{NC}$ increased throughout the 50 consecutive years analysed in this study. Average incidence rate for the five decades is $1 \%$. Rates increased from one decade to the other. They are above the average in the last three decades, the highest being registered for 1982-1991 (1.47\%). Technical progress on anti-cyst detection in the CSF can partly explain the increase 13. However, rates confirm that incidence of $\mathrm{NC}$ persists high 12. Also, they support the assumption that phophylactic measures scheduled for fighting taeniasis/cysticercosis are unadequately adopted in several regions 17. Prophylaxis in them is far beyond minimal needs for effectively fighting the parasitic cycle and neurocysti. cercosis as a consequence. This conclusion is illustrated by data reported in this study for a region of Brazil.

\section{REFERENCES}

1. Garcia E, Sotelo J. A new complement fixation test for the diagnosis of neurocysticercosis in cerebrospinal fluid. $J$ Neurol 1991, $238: 379-382$.

2. Lange O. Síndromo liquórico da cisticercose encéfalo meníngeta. Rev Neurol Psiquiat são Paulo 1940, 6:35-48. 
3. Livramento JA. Contribuição das reacões de imunofluorescência no líquido cefalorraqueano no estudo da neurocisticercose. Arq Neuro-Psiquiat (Bão Paulo) 1981, 39:261-278.

4. Machado LR. Liquido cefalorraqueano e neurocisticercose: aspectos evolutivos da resposta inflamatória celular. Arq Neuro-Psiquiat (São Paulo) 1987, 45:353-363.

5. Monteiro Sales F. Sobre o diagnóstico da cisticercose humana. Arq Inst Penido Burnier (Campinas) 1934, 3:183-196.

6. Moses A. Dos métodos biológicos de diagnóstico nas cisticercoses. Mem Inst Osłw Cruz 1911, 3:320-327.

7. Nieto D. Cysticercosis of the nervous system: diagnosis by means of the spinal fluid complement fixation test. Neurology 1956, 6:725-738.

8. Pessoa SB, Silveira GF, Correa C. Reação do desvio do complemento na cisticercose a Cysticercus cellulosae usando-se como antígeno extrato de Cysticercus bovis. Bol Inst Hyg São Paulo 1927, 24:9-12.

9. Reis JB, Bei A. A reação de fixação do complemento para o diagnóstico da sifilis e da cisticercose no líquido cefalorraquidiano pela técnica de Wadsworth, Maltaner e Maltaner. Rev Paul Med 1958, 53:439-458.

10. Reis JB Filho, Santos V. Reação de imunofluorescência indireta no diagnóstico da neurocisticercose. Neurobiologia (Recife) 1992, $55: 23-32$.

11. Spina-França A. Síndrome liquórica da neurocisticercose. Arq Neuro-Psiquiat (São Paulo) 1961, $19: 307-314$.

12. Spina-Franca A. Cysticercosis of the central nervous system. In Chopra JS, Jagannathan K, Sawhney IMS (eds): Advances in neurology. Amsterdam: Filsevier, 1990, p $283-291$.

13. Spina-França A, Livramento JA, Machado LR. Imunodiagnóstico da neurocisticercose: companação de resultados obtidos por técnicas diversas no líquido cefalorraqueano de 250 pacientes. XV Congresso Brasileiro de Neurologia. Porto Alegre: ABN, 1992.

14. Takayanagui $O M$, Jardím E. Aspectos clinicos da neurocisticercose: análise de 500 casos. Arq Neuro-Paiquiat (São Paulo) 1983, 41:50-63.

15. Trelles OJ, Trelles L. Cysticercosis of the nervous system. In Vinken PJ, Bruyn GI: (eds): Handbook of clinical neurology, Vol 35. Amsterdam: North-Holland, 1978, p 291-320.

16. Weinberg $M$. Recherche des anticorps spécifiques dans la distomatose et la cysticercose. C R Soc Biol 1909, 66:219-221.

17. World Federation of Neurology. News from the research groups; tropical neurology. World Neurol 1992, 7:7-9. 